\title{
Autosomal Recessive Spastic Ataxia of Charlevoix-Saguenay (ARSACS): Clinical, Radiological and Epidemiological Aspects
}

\author{
Haruo Shimazaki ${ }^{1}$ and Yoshihisa Takiyama ${ }^{2}$ \\ ${ }^{1}$ Division of Neurology, Department of Internal Medicine, \\ Jichi Medical University, Tochigi \\ ${ }^{2}$ Department of Neurology, Interdisciplinary Graduate School of Medicine and \\ Engineering, University of Yamanashi, Chuo-City, Yamanashi,
}

Japan

\section{Introduction}

Autosomal recessive spastic ataxia of Charlevoix-Saguenay (ARSACS) (OMIM \#270550) was originally found among inhabitants of the Charlevoix-Saguenay region of Quebec (Bouchard et al., 1978). ARSACS patients in Quebec show uniform phenotypes characterized by early-onset spastic ataxia, peripheral neuropathy, retinal hypermyelination, hand or foot deformities, and normal mentality. In 2000, the SACS gene, which is responsible for ARSACS, was identified in Quebec patients (Engert et al., 2000). Since then, ARSACS has been reported worldwide, especially in the Mediterranean area (El Euch-Fayache et al., 2003; Criscuolo et al., 2004; Grieco et al., 2004; Richter et al., 2004) and Japan (Ogawa et al., 2004; Takiyama, 2006). More SACS gene mutations were also identified in other areas (Takiyama, 2007; Ouyang et al., 2008; Vermeer et al., 2008; Gerwig et al., 2010). Meanwhile, ARSACS in non-Quebec patients, especially in Japanese ones, showed marked clinical heterogeneity, i.e., there were patients without spasticity (Shimazaki et al., 2005; Hara et al., 2007; Shimazaki et al., 2007), without retinal hypermyelination (Hara et al., 2007), and with decreased mentality (Shimazaki et al., 2005; Yamamoto et al., 2005; Shimazaki et al., 2007; Hara et al., 2005). The clinical spectrum of the sacsinpathies will expand with the identification of more SACS gene mutations (Gomez, 2004).

We herein review the epidemiology, genetics, clinical phenotypes, radiological and pathological findings in ARSACS cases carrying mutations of the SACS gene.

\section{Epidemiology}

\subsection{Quebec}

ARSACS is the most common of all inherited spastic ataxias, 320 affected patients having been identified in Quebec (Bouchard et al., 1998). In Quebec, most of the patients' families originate from the Charlevoix and Saguenay-Lac-St. Jean (SLSJ) regions. These regions have a population of about 300,000 inhabitants today that share a limited number of French 
ancestors who settled first in the Charlevoix region back in the seventeenth and early eighteenth centuries. ARSACS affects 1/1519 individuals in Charlevoix and 1/1952 in the Saguenay-Lac-St. Jean region, where the carrier frequency was estimated to be $1 / 22$ for the 1941-1985 period (De Braekeleer et al., 1993).

\subsection{Non-Quebec}

SACS gene identification has enabled us to find ARSACS patients worldwide outside Quebec: Tunisia (El Euch-Fayache et al., 2003) in 2003, Italy (Criscuolo et al., 2004; Grieco et al., 2004)in 2004, Japan (Ogawa et al., 2004) in 2004, and Turkey (Richter et al., 2004) in 2004. More cases were then reported in Spain (Criscuolo et al., 2005), France (Anheim et al., 2008), Belgium (Ouyang et al., 2008), the Netherlands (Vermeer et al., 2008), Germany (Gerwig et al., 2010), Maritime Canada (Guernsey et al., 2010), and Morocco and eastern Europe (Baets et al., 2010). In eastern France, ARSACS was identified in two index patients among 102 autosomal recessive cerebellar ataxia (ARCA) ones (Anheim et al., 2008), meanwhile among 43 Dutch ARCA patients, 16 with mutations in the SACS gene were identified (Vermeer et al., 2008). In Japan, 17 Japanese ARSACS families have been discovered on SACS gene analysis so far (Ogawa et al., 2004; Hara et al., 2005; Shimazaki et al., 2005; Yamamoto et al., 2005; Ouyang et al., 2006; Yamamoto et al., 2006; Okawa et al., 2006; Hara et al., 2007; Takado et al., 2007; Shimazaki et al., 2007; Kamada et al., 2008; Tsugawa et al., 2009; Haga et al., 2011; Miyatake et al., 2011; Komure et al., 2006). ARSACS might be the second most frequent ARCA next to ataxia with oculomotor apraxia 1 (AOA1) in Japan. Figure 1 shows the geographical distribution and numbers of ARSACS families with SACS gene mutations in Japan. We could not find apparent regional accumulation of ARSACS families in Japan. Table 1 lists the previously identified SACS gene mutations that we could confirm in the 17 Japanese ARSACS families. The mutations were unique ones for each family except for one missense mutation (W3248R) found in two unrelated families.

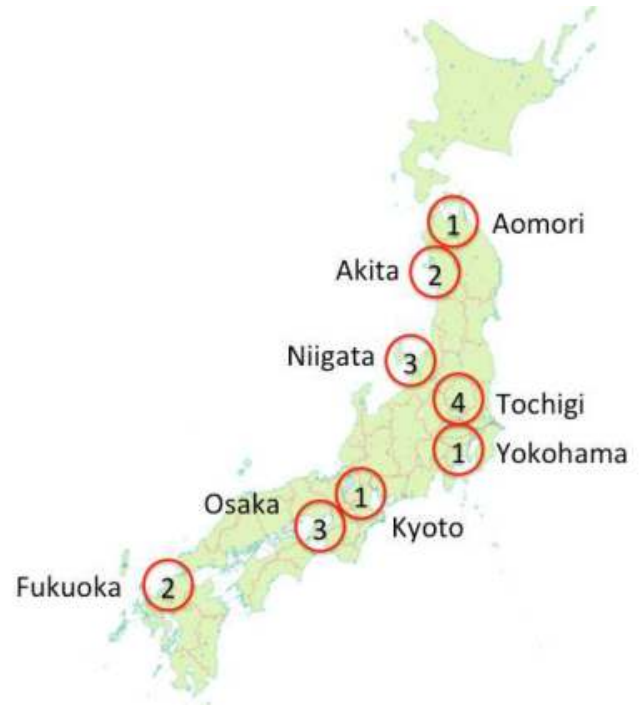

Fig. 1. Regional distribution of ARSACS families in Japan. 
ARSACS families show a nationwide distribution in Japan. The numbers in circles are the numbers of families identified in the regions.

\begin{tabular}{|c|c|c|c|}
\hline Amino acid substitutions & Exon & family & references \\
\hline W3248R & 10 & 2 & Ogawa, 2004, Takiyama, 2006 \\
\hline K2931fsX2952 & 10 & 1 & Hara, 2005 \\
\hline F1054S & 10 & 1 & Shimazaki, 2005 \\
\hline G1734fsX1736 & 10 & \multirow{2}{*}{1} & \multirow{2}{*}{ Yamamoto, 2005} \\
\hline S2058fsX2076 & 10 & & \\
\hline V1231del & 10 & \multirow{2}{*}{1} & \multirow{2}{*}{ Komure, 2006} \\
\hline P3559L & 10 & & \\
\hline Q1345X & 10 & 1 & Okawa, 2006 \\
\hline R4325X & 10 & 1 & Yamamoto, 2006 \\
\hline C395fsX407 & 8 & \multirow{2}{*}{1} & \multirow{2}{*}{ Ouyang, 2006} \\
\hline D687fs X713 & 8 & & \\
\hline R2119X & 10 & 1 & Hara, 2007 \\
\hline L308F & 8 & 1 & Takado, 2007 \\
\hline D1996fsX1999 & 10 & 1 & Shimazaki, 2007 \\
\hline N161fsX175 & 7 & \multirow{2}{*}{1} & \multirow{2}{*}{ Kamada, 2008} \\
\hline L802P & 10 & & \\
\hline G1257X & 10 & \multirow{2}{*}{1} & \multirow{2}{*}{ Tsugawa, 2009} \\
\hline R3788fsX3820 & 10 & & \\
\hline Y138X & 6 & \multirow{2}{*}{1} & \multirow{2}{*}{ Haga, 2011} \\
\hline K1755fsX1775 & 10 & & \\
\hline R3636X & 10 & 1 & (unpublished) \\
\hline S4007F & 10 & 1 & Miyatake, 2011 \\
\hline
\end{tabular}

Table 1. Previously identified SACS gene mutations in Japanese patients.

\section{Genetics}

\subsection{Gene structure and pathological mutations}

The SACS gene was originally reported to consist of a single gigantic exon spanning $12,794 \mathrm{bp}$ encoding an 11,487bp open reading frame (ORF), which represents the largest exon and the largest ORF within an exon found in any vertebrate (Engert et al., 2000). Recently, eight new exons located upstream of the gigantic one were found (Ouyang et al., 2006). More recently, one more upstream non-coding exon was found (Genbank NG_012342, 13- 
MAR-2011). The SACS gene comprises ten exons with a 13,737 bp ORF encoding 4579 amino acids (Figure 2A).

The SACS gene is predicted to encode a $520-\mathrm{kDa}$ multidomain protein, sacsin. The region near the C-terminus exhibits sequence similarity to the J-domain (DnaJ motif) of heat shock protein (HSP) 40 proteins (Parfitt et al., 2009), and the higher eukaryote and prokaryote nucleotide-binding (HEPN) domain (Grynberg, Erlandsen, and Godzik, 2003) (Figure 2B). A ubiquitin-like domain was identified at the N-terminus of sacsin (Parfitt et al., 2009)(Figure 2B). A sacsin repeating region (SRR) is present in triplicate at the $\mathrm{N}$-terminus of sacsin (Anderson, Siller, and Barral, 2010). A xeroderma pigmentosum complementation group Cbinding (XPCB) domain (Kamionka and Feigon, 2004) upstream of the DnaJ domain is also predicted.

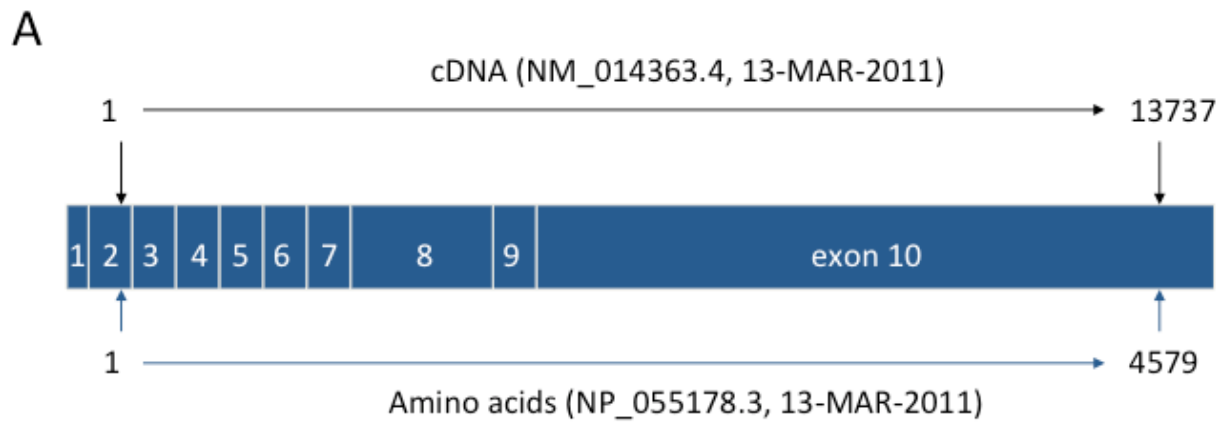

B

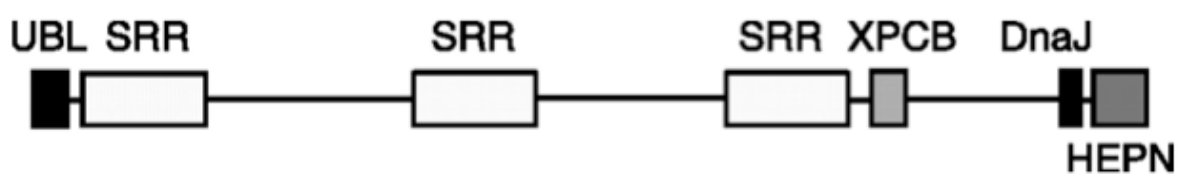

Fig. 2. Primary structure of the SACS gene (A) and domain organization of the sacsin protein (B). UBL: ubiquitin-like domain; SRR: sacsin repeating region; XPCB: XPC-binding domain; DnaJ: DnaJ motif (adopted from (Kozlov et al., 2011)).

Seventy-four mutations have been reported as pathological ones in the SACS gene (Baets et al., 2010). After publication of that report, we verified the table and found seven additional mutations in exons 6 and 10 of the SACS gene in Japanese patients (Table 1) (Komure et al., 2006; Tsugawa et al., 2009; Haga et al., 2011; Miyatake et al., 2011). As far as we know, at least 81 mutations have been found worldwide to date. Most of the mutations are predicted to generate truncated sacsin proteins, and are located in the largest exon, 10. Seventeen mutations were found in exons 4, 6, 7, 8 and 9. On copy number variation (CNV) analysis, an intragenic SACS deletion of exons 3-5 was identified (Baets et al., 2010). Two types of 
large deletions of the whole SACS gene and adjacent genes have been reported (Breckpot et al., 2008; Terracciano et al., 2009; McMillan et al., 2009).

\subsection{Normal sacsin function}

Sacsin is highly expressed in neurons, especially in cerebral corticospinal neurons and cerebellar Purkinje cells (Parfitt et al., 2009). The subcellular localization of sacsin in a cultured neuroblastoma-derived cell line was predominantly cytoplasmic and overlapped with that of mitochondrial protein heat shock protein (HSP) 60 (Parfitt et al., 2009). Because sacsin contains a functional J-domain (DnaJ motif), it has been proposed to act as a co-chaperone of the HSP70 chaperone system (Parfitt et al., 2009). The N-terminal segment of sacsin containing the ubiquitin-like (UbL) domain and the first sacsin repeating region (SRR) exhibits molecular chaperone activity and ATP-hydrolyzing activity (Anderson, Siller, and Barral, 2010, 2011). The UbL domain can interact with the $20 \mathrm{~S}$ proteasomal subunit (Parfitt et al., 2009). The HSP70 chaperone machinery is an important component of the cellular response to aggregation prone mutant proteins, and the $\mathrm{UbL}$ domain protein is a part of the quality control machinery that regulates protein aggregation. Overall, the main function of sacsin, like other molecular chaperones, is probably to prevent protein misfolding and aggregation. Sacsin prevents polyglutamineexpanded ataxin-1 toxicity (Parfitt et al., 2009). The XPCB domain interacts with ataxin-3, which is involved in spinocerebellar ataxia type 3 (Kamionka and Feigon, 2004). HEPN may stabilize nucleotide binding in complexes formed with the DnaJ domain (Grynberg, Erlandsen, and Godzik, 2003). Recently, the structure and function of the HEPN domain were determined, it being shown that it dimerizes and has a high affinity binding site for GTP, but it does not have GTPase activity (Kozlov et al., 2011).

\subsection{Pathogenesis of ARSACS}

Although the molecular mechanism underlying ARSACS remains unclear, the autosomal recessive transmission and truncating nature of most SACS mutations suggest the loss of sacsin function might cause development of this disease. Several functional alterations of sacsin proteins have been reported. An aspartate to tyrosine mutation (D168Y), located in the first SSR domain, abrogates its ATP-hydrolyzing activity (Anderson, Siller, and Barral, 2010). An asparagine to aspartate mutation (N4549D) in the HEPN domain of the sacsin protein disrupts dimerization and correct protein folding (Kozlov et al., 2011). Premature termination of other mutations and loss of the HEPN domain might lead to ARSACS disease.

\section{Clinical phenotypes}

\subsection{Original Quebec phenotype}

ARSACS is clinically characterized by early-onset spastic ataxia, axonal and demyelinating neuropathy, and hypermyelination of retinal nerve fibers (Bouchard et al., 1978; Bouchard, 1991). Unsteadiness of gait is usually the initial symptom. None of the patients ever walk normally, but walking is not delayed in most cases (rarely 
beyond 18 months of age) (Bouchard et al., 1978; Bouchard, 1991). The disease progression becomes most obvious in the late teens or early twenties, and the mean age for patients becoming wheelchair-bound is 41 years in Quebec patients (Bouchard, 1991). Concerning Quebec patients, ataxia, dysarthria, nystagmus, Babinski sign, hyperreflexia, spasticity, and retinal striations are noted in all of them. Distal amyotrophy of the feet is present in all patients after 20 years old (Bouchard, 1991), and pes cavus is noted in most Quebec patients. With these clinical features, ARSACS is clinically homogeneous in Quebec patients. Bouchard described progressive signs and early non-progressive ones of ARSACS in a review of this disease (Bouchard, 1991). The progressive signs are mostly spastic ataxia of the four limbs, slurred and dysrhythmic speech, discrete to severe distal amyotrophy, and absent ankle jerks after 25 years of age. The early non-progressive signs are increased deep tendon reflexes, a bilateral abnormal plantar response, marked saccadic alteration of smooth pursuit, and prominent myelinated fibers radiating from the disc on the retina.

\subsection{Non-Quebec atypical phenotypes}

The mean ages at onset are 5.4 and 4.5 years old in Japanese and Tunisian patients, respectively (Takiyama, 2007), while the ages at onset range from one to 1.5 years old in Quebec ones (Bouchard, 1991). Thus, the age at onset in these non-Quebec patients seems to be later than that in Quebec patients. According to a recent report from Belgium, the disease onset was over 20 years in five patients and as late as 40 years in one patient (Baets et al., 2010).

Although ataxia is noted in all non-Quebec ARSACS patients, one report stated that the cerebellar features were very mild in two patients (Baets et al., 2010). Other core clinical features of ARSACS, i.e., dysarthria, nystagmus, distal amyotrophy, Babinski sign, hyperreflexia, and pes cavus, are noted in most non-Quebec patients, which are similar to in Quebec patients.

Non-Quebec patients, however, show some atypical features in comparison with Quebec ones. First, although spasticity is a core clinical feature of ARSACS, we found that two patients in a Japanese family with ARSACS lacked spasticity in the legs and showed areflexia or hyporeflexia (Shimazaki et al., 2005). In Quebec and Tunisian patients, spasticity becomes progressively worse during the disease course and is prevalent in older patients, and tendon reflexes remain preserved throughout the disease, except for ankle jerks (Bouchard et al., 1978; El Euch-Fayache et al., 2003). Since we did not observe the two above patients in their childhood, we were not able to determine whether or not their spasticity had decreased during the disease course or had been absent from the onset (Shimazaki et al., 2005). The cases without spasticity, this depended on the fact that the neuromuscular manifestations were severe enough to diminish muscle tone and masked spasticity, and the planter responses were extensor, demonstrating that pyramidal tract sign was present. Recently, however, we observed another ARSACS patient whose spasticity had disappeared, probably due to the progressive peripheral nerve degeneration in the disease course of 29 years (Shimazaki et al., 2007). Thus, we should recognize that there is a rare ARSACS phenotype without spasticity, and the SACS gene should be analyzed even in 
cases of early-onset cerebellar ataxia without spasticity. After that, several reports on spasticity-lacking ARSACS patients were published (Hara et al., 2007; Baets et al., 2010; Miyatake et al., 2011).

Second, intellectual impairment is sometimes found in non-Quebec patients. The verbal IQ was 58, 88, 100, and 66 (mean: 78.00) in the four Japanese patients we examined (Takiyama, 2006). Similarly, mental retardation and dementia have been found in Italy (Criscuolo et al., 2004), Japan (Hara et al., 2005), and Turkey (Richter et al., 2004). Meanwhile, the verbal IQ (mean: 92.67) of Quebec patients is considered to be within normal limits, and a number of ARSACS patients have completed the secondary and university levels of education (Bouchard, 1991). Thus, intellectual impairment seems to be variable in ARSACS. Since the mode of inheritance of ARSACS is autosomal recessive, genes other than SACS might influence the intellectual impairment.

Defects in conjugate pursuit ocular movements, decreased or absent vibration sense in the toes, hand deformities, and urinary or fecal incontinence are rather frequently noted in Quebec (Bouchard, 1991) and non-Quebec patients (El Euch-Fayache et al., 2003; Takiyama, 2006). Cardiovascular evaluation revealed mitral valve prolapse in a majority of Quebec patients examined (Bouchard, 1991).

Very recently, the disease initially presented with symptoms mainly orienting toward peripheral neuropathy in several patients, and there was one patient who did not exhibit any clinical or electrophysiologic signs of peripheral neuropathy (Baets et al., 2010).

\subsection{Ophthalmologic findings}

Although increased visibility of myelinated retinal nerve fibers is a hallmark of ARSACS in Quebec patients (Bouchard, 1991), there have been a considerable number of non-Quebec patients without this characteristic sign for ARSACS (El Euch-Fayache et al., 2003; Grieco et al., 2004; Criscuolo et al., 2004; Richter et al., 2004; Hara et al., 2005; Yamamoto et al., 2005; Ouyang et al., 2006; Okawa et al., 2006; Yamamoto et al., 2006; Hara et al., 2007; Baets et al., 2010). Thus, retinal hypermyelination is a variable feature in non-Quebec patients. It is, however, very useful for suspecting a diagnosis of ARSACS, especially in an unusual phenotype without spasticity (Shimazaki et al., 2005). In a case without retinal hypermyelination, ARSACS resembles conditions referred to as early onset cerebellar ataxia with retained tendon reflexes (EOCA) (Chio et al., 1993), Friedreich ataxia with retained reflexes (De Castro et al., 1999), and several clinical descriptions of hereditary spastic paraplegia such as SPG7 (Wilkinson et al., 2004), SPG21 (Simpson et al., 2003), SPG27 (Meijer et al., 2004), and SPG30 (Klebe et al., 2006).

Recently, Desserre et al. have reported that the retinal nerve fiber layer was thickened, as shown using optical coherence tomography (OCT), and that the retina did not show hypermyelinated areas on funduscopy (Desserre et al., 2011). Likewise, Vingolo et al. reported that four patients with ARSACS showed myelinated fibers on funduscopy, and also increased thickness of the retina on OCT, which is a finding not characteristic of persistent myelination of the retina (Vingolo et al., 2011). It is possible that persistent myelination of the retina, a general common finding, was present in those patients without bearing relation to the disease. 


\section{Neuroradiology}

\subsection{Brain MRI findings}

Some reports have mentioned that characteristic MRI findings in ARSACS are superior cerebellar vermian atrophy and cervical spinal cord atrophy (Bouchard et al., 1998; Takiyama, 2007). Recently, MRI of five patients in Quebec revealed linear hypointensity in T2- and Fluid-Attenuated Inversion Recovery (FLAIR) images of the pons (Martin et al., 2007). Thereafter, the same findings have been reported in only one patient in each of the Netherlands (Van Damme et al., 2009), France (Anheim et al., 2010), and Italy (Terracciano et al., 2010).

We recruited six ARSACS patients with SACS mutations in four Japanese families. Brain MRI was performed in all six patients. Brain MRI in the six patients showed superior cerebellar vermian atrophy. In addition, not only pontine linear hypointensity but also middle cerebellar peduncle hypointensity was observed in T2-weighted and FLAIR images (Shimazaki et al., in press) (Table 2). These areas showed isointensity in T1-weighted images. Figure 3 shows representative brain MRI findings in patients 3 (A) and 2 (B). In patient 3 , T2*-weighted images were obtained showing no abnormal findings in the pons and middle cerebellar peduncles (Figure 3, A-1).

We found the characteristic MRI findings in the six Japanese ARSACS patients, who all exhibited linear hypointensity in the pons, and a hypointense area in the middle cerebellar peduncles in T2-weighted and FLAIR images (Shimazaki et al., in press). A middle cerebellar peduncle hypointense area has not previously been reported in ARSACS patients, although pontine linear hypointensity was originally reported in five Quebec patients (Martin et al., 2007). Furthermore, as far as we know, hypointensity in these portions has not been described as a MRI finding in spinocerebellar ataxias and hereditary spastic paraplegias.

We thought these hypointense areas were close to the location of the pontocerebellar fibers. We could find low intensity in the middle cerebellar peduncle (MCP) because the pontocerebellar fiber runs from the middle pons to the cerebellum through the MCP. We can detect low MCP intensity in an Italian case (Terracciano et al., 2010). We think an abnormal MCP signal is not specific for Japanese patients.

The hypointensity in the pons and middle cerebellar peduncle might be specific findings for ARSACS cases even in non-Quebec ones with clinical heterogeneity (Shimazaki et al., 2012). Thus, pontine and middle cerebellar peduncle T2 hypointensity detectable on MRI should prompt us to perform SACS gene analysis even in such atypical early-onset cerebellar ataxia cases.

\subsection{Spinal MRI findings}

In Quebec cases, the cervical cord is small and flat (Bouchard, 1991). In our cases, upper cervical cord and medulla oblongata atrophy was not observed in three of the six patients for whom cervical MRI was performed (Shimazaki et al., 2012). Upper cervical atrophy is not a constant feature of ARSACS. In thirteen Belgium cases, cervical spinal cord atrophy was observed on MRI in only one case (Baets et al., 2010). 
Autosomal Recessive Spastic Ataxia of Charlevoix-

\begin{tabular}{|c|c|c|c|c|c|c|}
\hline Case & 1 & 2 & 3 & 4 & 5 & 6 \\
\hline $\begin{array}{c}\text { Age at exam, } \\
\text { gender }\end{array}$ & $47, \mathrm{~F}$ & $43, \mathrm{M}$ & $46, \mathrm{M}$ & $37, \mathrm{M}$ & $33, \mathrm{M}$ & $57, \mathrm{~F}$ \\
\hline Age at onset & 6 & 6 & 3 & 8 & 7 & 3 \\
\hline $\begin{array}{c}\text { Cerebellar } \\
\text { ataxia }\end{array}$ & ++ & + & ++ & + & ++ & ++ \\
\hline Hyperreflexia & + & + & + & - & - & - \\
\hline Leg spasticity & + & + & + & - & - & - \\
\hline Babinski sign & + & + & + & + & + & + \\
\hline $\begin{array}{c}\text { Retinal } \\
\text { myelinated } \\
\text { fibers }\end{array}$ & + & + & + & + & + & + \\
\hline $\begin{array}{l}\text { Peripheral } \\
\text { neuropathy }\end{array}$ & + & + & + & + & + & + \\
\hline $\begin{array}{c}\text { Mental } \\
\text { impairment }\end{array}$ & NE & +(WAIS-R) & $+($ WAIS-R) & $\mathrm{NE}$ & +(WAIS-R) & $+($ MMSE) \\
\hline $\begin{array}{l}\text { Amino acid } \\
\text { substitutions }\end{array}$ & W3248R & W3248R & W3248R & F1054S & F1054S & D1996fsX1999 \\
\hline $\begin{array}{l}\text { Superior } \\
\text { cerebellar } \\
\text { vermian } \\
\text { atrophy }\end{array}$ & + & + & + & + & + & + \\
\hline $\begin{array}{l}\text { Pontine linear } \\
\text { hypointensity } \\
\text { (T2) }\end{array}$ & + & + & + & + & + & + \\
\hline $\begin{array}{c}\mathrm{MCP} \\
\text { hypointensity } \\
\text { (T2) }\end{array}$ & + & + & + & + & + & + \\
\hline $\begin{array}{c}\text { Medulla } \\
\text { oblongata } \\
\text { atrophy }\end{array}$ & - & - & + & + & + & - \\
\hline $\begin{array}{l}\text { Upper cervical } \\
\text { cord atrophy }\end{array}$ & - & - & + & + & + & - \\
\hline $\begin{array}{c}\text { Superior } \\
\text { cerebellar } \\
\text { CBF decrease }\end{array}$ & +- & NE & +- & + & + & + \\
\hline
\end{tabular}

Table 2. Clinical, genetic and MRI findings in the ARSACS patients. NE: not examined; MCP: Middle cerebellar peduncle; CBF: cerebral blood flow in SPECT. 

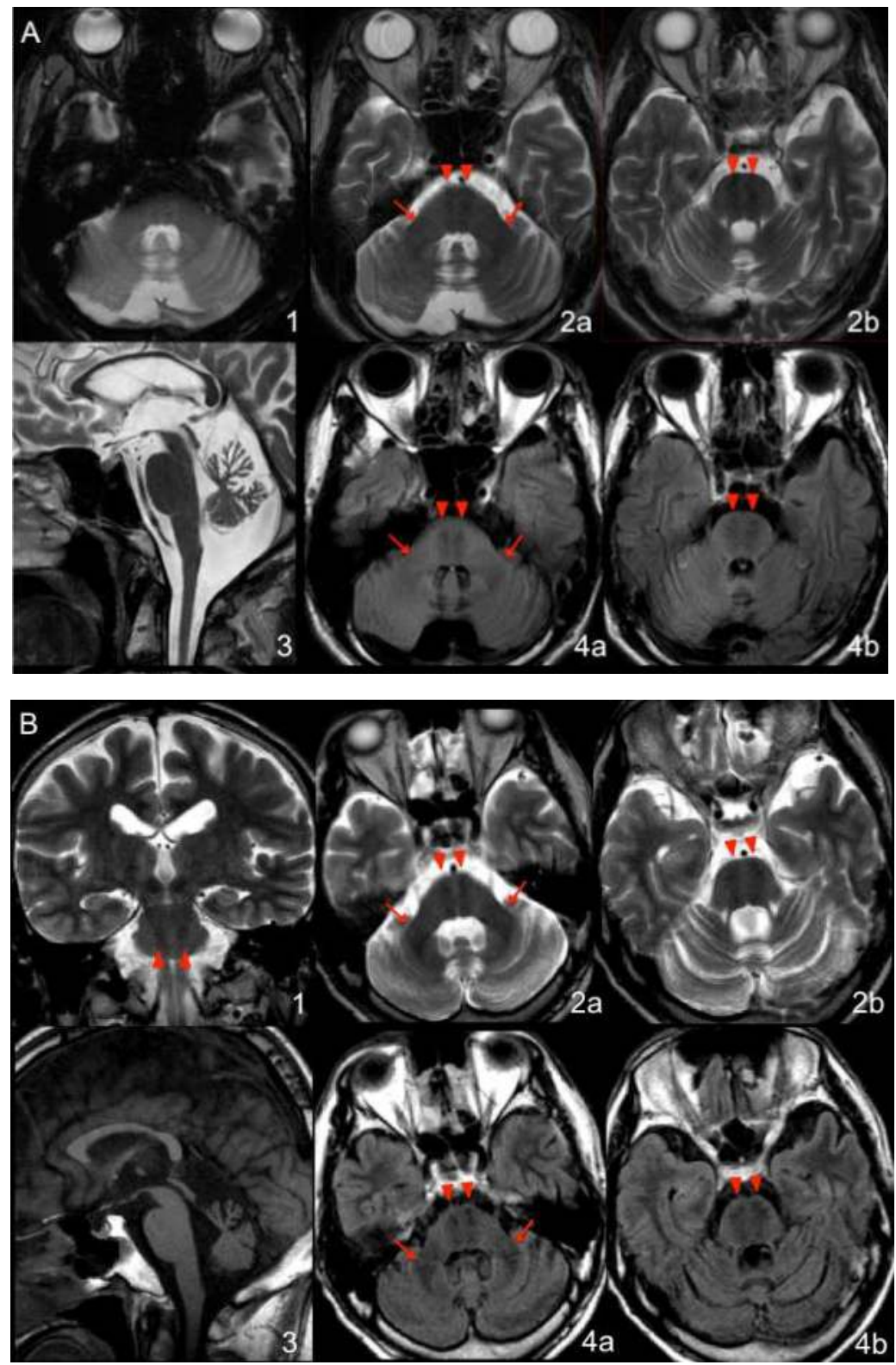

Fig. 3. Representative brain MRI findings in two ARSACS patients. T2-weighted and FLAIR images of patient 3 (A-2a, 2b, 4a, and 4b) and patient 2 (B-1, 2a, 2b, 4a, and 4b) showed hypointensity in the pons (arrowheads) and bilateral middle cerebellar peduncles (arrows). Sagittal sections (A-3 and B-3) revealed superior cerebellar vermian atrophy in all patients. A T2* image of patient 3 (A-1) disclosed no remarkable low intensity in the pontine tegmentum or cerebellar peduncles (Shimazaki et al., 2012). 


\subsection{SPECT findings}

Single photon emission computed tomography (SPECT) of the brain with three-dimensional stereotactic surface projection (3D-SSP) analysis for five cases showed decreased blood flow in the upper cerebellar vermis in three cases (Shimazaki et al., 2007; Shimazaki, Nakano, and Takiyama, 2008) (Figure 4). Meanwhile, early onset cerebellar ataxia with retained tendon reflexes (EOCA) and Friedreich's ataxia often show a reduction in the parietotemporal cortex blood flow as well as cerebellar hypoperfusion (De Michele et al., 1998), this being a different feature from in ARSACS.

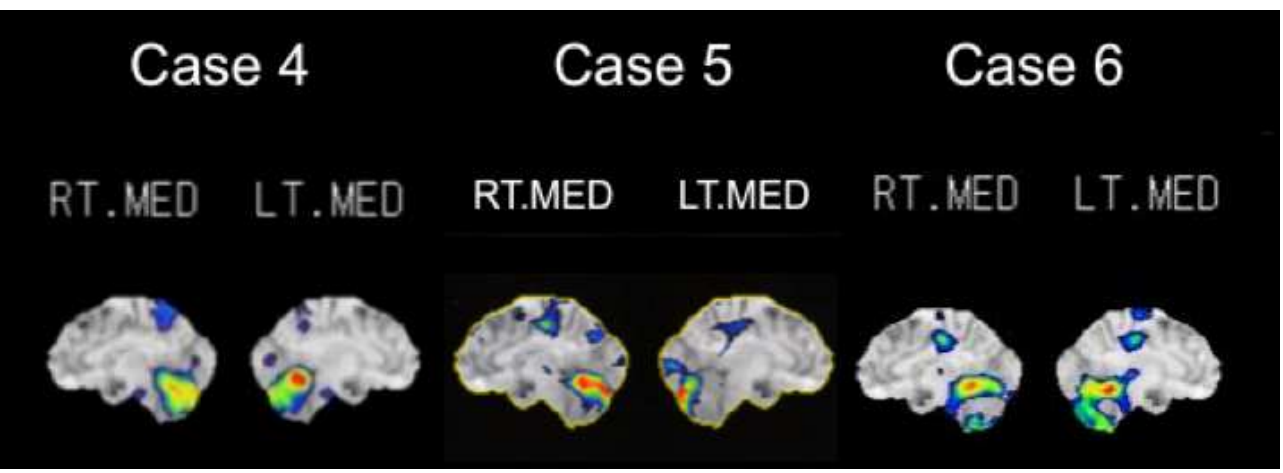

Fig. 4. ${ }^{123 I-I M P ~ S P E C T ~ w i t h ~ t h r e e-d i m e n s i o n a l ~ s t e r e o t a c t i c ~ s u r f a c e ~ p r o j e c t i o n ~(3 D-S S P) ~}$ analyses of cases 4,5 , and 6 .

The results showed decreased blood flow in the superior cerebellar vermis and cerebellar hemisphere.

\section{Neuropathology}

\subsection{Postmortem autopsy and comparison with the characteristic brain MRI findings}

The pathological findings in ARSACS patients have only been reported in a 21-year-old man (Bouchard, 1991) and a 59-year-old man (Richter et al., 1996). The former report of a young man described no findings regarding pontocerebellar fibers, but mentioned a small corticospinal tract and normal pontine nuclei in the pons (Bouchard, 1991). A T2* image of patient 3 disclosed no remarkable low intensity in the pontine tegmentum or cerebellar peduncles. These findings suggest that T2 hypointensity in the pons and cerebellar peduncles is not reflected by iron deposition in these portions. However, a second autopsy on the 59-year-old man revealed the presence of swollen thalamic and cerebellar cortical neurons (Bouchard et al., 1998). Most of these neurons had dense, lipofuscin-like granules within their lysosomes, and the authors suggested that ARSACS may be a lysosomal storage disease (Richter et al., 1996). In neuronal ceroid lipofuscinosis, MRI can often reveal hypointensity of the thalamus and putamen in T2-weighted images, which may reflect the storage of lipofuscin and the increase in the viscosity in these neurons (Autti, Joensuu, and Aberg, 2007). Therefore, the linear hypointensity of the pons that was found among ARSACS patients can also be explained by possible storage of lipofuscin-like materials. Further pathological study is needed to disclose the origin of the T2 hypointensity. 


\subsection{Nerve and muscle biopsy}

Sural nerve biopsy revealed severe axonal degeneration and loss of large myelinated fibers (Peyronnard, Charron, and Barbeau, 1979; Bouchard, 1991; El Euch-Fayache et al., 2003; Takiyama, 2006). These findings in Quebec and non-Quebec patients are consistent with an axonal neuropathy associated with demyelinating features.

Muscle biopsy disclosed typical and obvious neurogenic atrophy, i.e., grouped atrophy in the studied patients (Bouchard, 1991; El Euch-Fayache et al., 2003).

\section{Neurophysiology}

\subsection{Peripheral nerve conduction studies}

The peripheral nerve conduction study in Quebec patients revealed an axonal neuropathy with absent sensory action potentials and low motor conduction velocity (Peyronnard, Charron, and Barbeau, 1979; Bouchard, 1991). We have presented the peripheral nerve conduction data for cases 4 and 5 (Shimazaki et al., 2005). In each patient, the motor nerve conduction velocity was mildly reduced in the ulnar and median nerves, and moderately in the posterior tibial nerves. Each compound muscle action potential (CMAP) was markedly decreased. In case 5 (patient 1 of (Shimazaki et al., 2005)), a CMAP was not evoked in the common peroneal nerves. No sensory nerve action potential was evoked in any of the extremities. These data indicate not only a severe to moderate axonal neuropathy but dysmyelinating neuropathy complicated by secondary axonal degeneration as in Quebec and Tunisian patients (Peyronnard, Charron, and Barbeau, 1979; El Euch-Fayache et al., 2003).

\subsection{Motor and sensory evoked potentials}

Central pathway conduction studies including ones on somatosensory evoked potentials, brainstem auditory evoked potentials, and pattern reversal visual evoked potentials were performed in 67 Quebec patients (De Lean, Mathieu, and Bouchard, 1989). The findings that showed marked delays revealed widespread processes of demyelination in the primary sensory neurons as well as in the central nervous system (Bouchard, 1991). The central sensory and motor pathways were markedly impaired that could be attributed to myelinopathies, and there were high incidences of asymptomatic auditory and visual pathway involvement (Bouchard, 1991).

Electronystagmography showed horizontal gaze nystagmus in all Quebec patients with marked impairment of smooth ocular pursuit and optokinetic nystagmus, and defective fixation suppression of caloric nystagmus (Dionne et al., 1979). Recently, both the masseter and blink reflexes were found to be abnormal in two ARSACS patients (Garcia et al., 2008), whereas the masseter reflex was preserved but a bilateral delay of the late response of the blink reflex was observed in Friedreich' ataxia patients.

\section{Therapy and management}

Spasticity, the main feature of ARSACS during childhood, is rather mild in most patients. In the teens, however, the spasticity increases in the lower limbs and patients often present a 
spastic gait with evolving pes cavus (Bouchard et al., 2007). Physical therapy and use of oral medications such as baclofen to control spasticity in the early phase of the disease may prevent tendon shortening and joint contractures. When spasticity becomes significant, intrathecal baclofen may be considered. The most effective surgical procedures were triple arthrodesis with percutaneous lengthening of the Achilles tendon, and adductor and psoas tenotomies combined with neurectomy of the obturator nerve for perineal hygiene in a retrospective study of 26 patients who received surgical orthopaedic treatment (Bouchard and Langlois, 1999).

\section{Acknowledgements}

This work was supported by Grants-in Aid from the Research Committee for Ataxic Diseases (Y.T. and H.S.), the Ministry of Health, Labour and Welfare of Japan - This work was also supported by Grants-in-Aid from the Research Committee of CNS Degenerative Diseases (Y.T.), and the Ministry of Health, Labor and Welfare of Japan, and supported by a Grant-in-Aid for Scientific Research (C) (23591253 to H.S.) from The Ministry of Education, Culture, Sports, Science and Technology in Japan.

\section{References}

Anderson, J. F., E. Siller, and J. M. Barral. (2010). The sacsin repeating region (SRR): a novel Hsp90-related supra-domain associated with neuro-degeneration. J Mol Biol, Vol.400, No.4, (Jul 2010), pp. 665-674, ISSN 1089-8638

Anderson, J. F., E. Siller, and J. M. Barral. (2011). The Neurodegenerative- Disease-Related Protein Sacsin Is a Molecular Chaperone. J Mol Biol, (Jun 2011), [Epub ahead of print], ISSN 1089-8638

Anheim, M., D. Chaigne, M. Fleury, F. M. Santorelli, J. De Seze, A. Durr, A. Brice, M. Koenig, and C. Tranchant. (2008). [Autosomal recessive spastic ataxia of Charlevoix-Saguenay: study of a family and review of the literature]. Rev Neurol (Paris), Vol.164, No.4, (Apr 2008), pp. 363-368, ISSN 0035-3787

Anheim, M., M. Fleury, B. Monga, V. Laugel, D. Chaigne, G. Rodier, E. Ginglinger, C. Boulay, S. Courtois, N. Drouot, M. Fritsch, J. P. Delaunoy, D. Stoppa-Lyonnet, C. Tranchant, and M. Koenig. (2010). Epidemiological, clinical, paraclinical and molecular study of a cohort of 102 patients affected with autosomal recessive progressive cerebellar ataxia from Alsace, Eastern France: implications for clinical management. Neurogenetics, Vol.11, No.1, (Feb 2010), pp. 1-12, ISSN 1364-6753

Autti, T., R. Joensuu, and L. Aberg. (2007). Decreased T2 signal in the thalami may be a sign of lysosomal storage disease. Neuroradiology, Vol.49, No.7, (Jul 2007), pp. 571-578, ISSN 0028-3940

Baets, J., T. Deconinck, K. Smets, D. Goossens, P. Van den Bergh, K. Dahan, E. Schmedding, P. Santens, V. M. Rasic, P. Van Damme, W. Robberecht, L. De Meirleir, B. Michielsens, J. Del-Favero, A. Jordanova, and P. De Jonghe. (2010). Mutations in SACS cause atypical and late-onset forms of ARSACS. Neurology, Vol.75, No.13, (Sep 2010), pp. 1181-1188, ISSN 0028-3878

Bouchard, J. P. (1991). Ressesive spastic ataxia of Charlevoix-Saguenay. In Hereditary Neuropathies and Spinocerebellar Atrophies. Handbook of Clinical Neurology, edited by J. M. B. V. de Jong, pp. 451-459, Elsevier, ISBN 0-444-81279-2 , Amsterdam. 
Bouchard, J. P., A. Barbeau, R. Bouchard, and R. W. Bouchard. (1978). Autosomal recessive spastic ataxia of Charlevoix-Saguenay. Can J Neurol Sci, Vol.5, No.1, (Feb 1978), pp. 61-69, ISSN 0317-1671

Bouchard, J. P., B. Brais, N. Dupre, and G. A. Rouleau. (2007). Hereditary ataxias and spastic parapareses in northeastern Canada. In Spinocerebellar Degenerations: The Ataxias and Spastic Paraplegias, Blue Books of Neurology, edited by A. Brice and S. M. Pulst, pp. 222-243, Elsevier, ISBN 0-7506-7503-9, Amsterdam.

Bouchard, J. P., A. Richter, J. Mathieu, D. Brunet, T. J. Hudson, K. Morgan, and S. B. Melancon. (1998). Autosomal recessive spastic ataxia of Charlevoix-Saguenay. Neuromuscul Disord, Vol.8, No.7, (Oct 1998), pp. 474-479, ISSN 0960-8966

Bouchard, M., and G. Langlois. (1999). Orthopedic management in autosomal recessive spastic ataxia of Charlevoix-Saguenay. Can J Surg, Vol.42, No.6, (Dec 1999), pp. 440444, ISSN 0008-428X

Breckpot, J., Y. Takiyama, B. Thienpont, S. Van Vooren, J. R. Vermeesch, E. Ortibus, and K. Devriendt. (2008). A novel genomic disorder: a deletion of the SACS gene leading to spastic ataxia of Charlevoix-Saguenay. Eur J Hum Genet, Vol.16, No.9, (Sep 2008), pp. 1050-1054, ISSN 1018-4813

Chio, A., L. Orsi, P. Mortara, and D. Schiffer. (1993). Early onset cerebellar ataxia with retained tendon reflexes: prevalence and gene frequency in an Italian population. Clin Genet, Vol.43, No.4, (Apr 1993), pp. 207-211, ISSN 0009-9163

Criscuolo, C., S. Banfi, M. Orio, P. Gasparini, A. Monticelli, V. Scarano, F. M. Santorelli, A. Perretti, L. Santoro, G. De Michele, and A. Filla. (2004). A novel mutation in SACS gene in a family from southern Italy. Neurology, Vol.62, No.1, (Jan 2004), pp. 100102, ISSN 0028-3878

Criscuolo, C., F. Sacca, G. De Michele, P. Mancini, O. Combarros, J. Infante, A. Garcia, S. Banfi, A. Filla, and J. Berciano. (2005). Novel mutation of SACS gene in a Spanish family with autosomal recessive spastic ataxia. Mov Disord, Vol.20, No.10, (Oct 2005), pp. 1358-1361, ISSN 0885-3185

De Braekeleer, M., F. Giasson, J. Mathieu, M. Roy, J. P. Bouchard, and K. Morgan. (1993). Genetic epidemiology of autosomal recessive spastic ataxia of Charlevoix-Saguenay in northeastern Quebec. Genet Epidemiol, Vol.10, No.1, (1993), pp. 17-25, ISSN 07410395

De Castro, M., A. Cruz-Martinez, J. J. Vilchez, T. Sevilla, M. Pineda, J. Berciano, and F. Palau. (1999). Early onset cerebellar ataxia and preservation of tendon reflexes: clinical phenotypes associated with GAA trinucleotide repeat expanded and non-expanded genotypes. J Peripher Nerv Syst, Vol.4, No.1, (1999), pp. 58-62, ISSN 1085-9489

De Lean, J., J. Mathieu, and J. P. Bouchard. (1989). Central pathway conduction in recessive ataxia of Charlevoix-Saguenay. Can J Neurol Sci, Vol.16, (1989), pp. 272, ISSN 03171671

De Michele, G., P. P. Mainenti, A. Soricelli, F. Di Salle, E. Salvatore, M. R. Longobardi, A. Postiglione, M. Salvatore, and A. Filla. (1998). Cerebral blood flow in spinocerebellar degenerations: a single photon emission tomography study in 28 patients. J Neurol, Vol.245, No.9, (Sep 1998), pp. 603-608, ISSN 0340-5354

Desserre, J., D. Devos, B. G. Sautiere, P. Debruyne, F. M. Santorelli, I. Vuillaume, and S. Defoort-Dhellemmes. (2011). Thickening of Peripapillar Retinal Fibers for the 
Diagnosis of Autosomal Recessive Spastic Ataxia of Charlevoix-Saguenay. Cerebellum, (May 2011), [Epub ahead of print], ISSN 1473-4230

Dionne, J., G. Wright, H. Barber, R. Bouchard, and J. P. Bouchard. (1979). Oculomotor and vestibular findings in autosomal recessive spastic ataxia of Charlevoix-Saguenay. Can J Neurol Sci, Vol.6, No.2, (May 1979), pp. 177-184, ISSN 0317-1671

El Euch-Fayache, G., I. Lalani, R. Amouri, I. Turki, K. Ouahchi, W. Y. Hung, S. Belal, T. Siddique, and F. Hentati. (2003). Phenotypic features and genetic findings in sacsinrelated autosomal recessive ataxia in Tunisia. Arch Neurol, Vol.60, No.7, (Jul 2003), pp. 982-988, ISSN 0003-9942

Engert, J. C., P. Berube, J. Mercier, C. Dore, P. Lepage, B. Ge, J. P. Bouchard, J. Mathieu, S. B. Melancon, M. Schalling, E. S. Lander, K. Morgan, T. J. Hudson, and A. Richter. (2000). ARSACS, a spastic ataxia common in northeastern Quebec, is caused by mutations in a new gene encoding an 11.5-kb ORF. Nat Genet, Vol.24, No.2, (Feb 2000), pp. 120-125, ISSN 1061-4036

Garcia, A., C. Criscuolo, G. de Michele, and J. Berciano. (2008). Neurophysiological study in a Spanish family with recessive spastic ataxia of Charlevoix-Saguenay. Muscle Nerve, Vol.37, No.1, (Jan 2008), pp. 107-110, ISSN 0148-639X

Gerwig, M., S. Kruger, F. R. Kreuz, S. Kreis, E. R. Gizewski, and D. Timmann. (2010). Characteristic MRI and funduscopic findings help diagnose ARSACS outside Quebec. Neurology, Vol.75, No.23, (Dec 2010), p. 2133, ISSN 1526-632X

Gomez, C. M. (2004). ARSACS goes global. Neurology, Vol.62, No.1, (Jan 2004), pp. 10-11, ISSN 0028-3878

Grieco, G. S., A. Malandrini, G. Comanducci, V. Leuzzi, M. Valoppi, A. Tessa, S. Palmeri, L. Benedetti, A. Pierallini, S. Gambelli, A. Federico, F. Pierelli, E. Bertini, C. Casali, and F. M. Santorelli. (2004). Novel SACS mutations in autosomal recessive spastic ataxia of Charlevoix-Saguenay type. Neurology, Vol.62, No.1, (Jan 2004), pp. 103106, ISSN 0028-3878

Grynberg, M., H. Erlandsen, and A. Godzik. (2003). HEPN: a common domain in bacterial drug resistance and human neurodegenerative proteins. Trends Biochem Sci, Vol.28, No.5, (May 2003), pp. 224-226, ISSN 0968-0004

Guernsey, D. L., M. P. Dube, H. Jiang, G. Asselin, S. Blowers, S. Evans, M. Ferguson, C. Macgillivray, M. Matsuoka, M. Nightingale, A. Rideout, M. Delatycki, A. Orr, M. Ludman, J. Dooley, C. Riddell, and M. E. Samuels. (2010). Novel mutations in the sacsin gene in ataxia patients from Maritime Canada. J Neurol Sci, Vol.288, No.1-2, (Jan 2010), pp. 79-87, ISSN 1878-5883

Haga, R., Y. Miki, Y. Funamizu, T. Kon, C. Suzuki, T. Ueno, H. Nishijima, A. Arai, M. Tomiyama, H. Shimazaki, Y. Takiyama, and M. Baba. (2011). Novel compound heterozygous mutations of the SACS gene in autosomal recessive spastic ataxia of Charlevoix-Saguenay. Clin Neurol Neurosurg, (Dec 30 2011), [Epub ahead of print] , ISSN 1872-6968

Hara, K., O. Onodera, M. Endo, H. Kondo, H. Shiota, K. Miki, N. Tanimoto, T. Kimura, and M. Nishizawa. (2005). Sacsin-related autosomal recessive ataxia without prominent retinal myelinated fibers in Japan. Mov Disord, Vol.20, No.3, (Mar 2005), pp. 380382, ISSN 0885-3185 
Hara, K., J. Shimbo, H. Nozaki, K. Kikugawa, O. Onodera, and M. Nishizawa. (2007). Sacsinrelated ataxia with neither retinal hypermyelination nor spasticity. Mov Disord, Vol.22, No.9, (Jul 2007), pp. 1362-1363, ISSN 0885-3185

Kamada, S., S. Okawa, T. Imota, M. Sugawara, and I. Toyoshima. (2008). Autosomal recessive spastic ataxia of Charlevoix-Saguenay (ARSACS): novel compound heterozygous mutations in the SACS gene. J Neurol, Vol.255, No.6, (Jun 2008), pp. 803-806, ISSN 0340-5354

Kamionka, M., and J. Feigon. (2004). Structure of the XPC binding domain of hHR23A reveals hydrophobic patches for protein interaction. Protein Sci, Vol.13, No.9, (Sep 2004), pp. 2370-2377, ISSN 0961-8368

Klebe, S., H. Azzedine, A. Durr, P. Bastien, N. Bouslam, N. Elleuch, S. Forlani, C. Charon, M. Koenig, J. Melki, A. Brice, and G. Stevanin. (2006). Autosomal recessive spastic paraplegia (SPG30) with mild ataxia and sensory neuropathy maps to chromosome 2q37.3. Brain, Vol.129, No.Pt 6, (Jun 2006), pp. 1456-1462, ISSN 1460-2156

Komure, O., E. Murase, T. Saida, M. Nakamura, T. Sano, M. Sanada, and K. Ozawa. (2006). An ARSACS family with compound heterozygous SACS gene mutations. Rinsho Shinkeigaku, Vol.46, No.12, (Dec 2006), pp. 1018, ISSN 0009-918X

Kozlov, G., A. Y. Denisov, M. Girard, M. J. Dicaire, J. Hamlin, P. S. McPherson, B. Brais, and K. Gehring. (2011). Structural Basis of Defects in the Sacsin HEPN Domain Responsible for Autosomal Recessive Spastic Ataxia of Charlevoix-Saguenay (ARSACS). J Biol Chem, Vol.286, No.23, (Jun 2011), pp. 20407-20412, ISSN 1083-351X

Martin, M. H., J. P. Bouchard, M. Sylvain, O. St-Onge, and S. Truchon. (2007). Autosomal recessive spastic ataxia of Charlevoix-Saguenay: a report of MR imaging in 5 patients. Am J Neuroradiol, Vol.28, No.8, (Sep 2007), pp. 1606-1608, ISSN 0195-6108

McMillan, H. J., M. T. Carter, P. J. Jacob, E. E. Laffan, M. D. O'Connor, and K. M. Boycott. (2009). Homozygous contiguous gene deletion of 13q12 causing LGMD2C and ARSACS in the same patient. Muscle Nerve, Vol.39, No.3, (Mar 2009), pp. 396-399, ISSN 0148-639X

Meijer, I. A., P. Cossette, J. Roussel, M. Benard, S. Toupin, and G. A. Rouleau. (2004). A novel locus for pure recessive hereditary spastic paraplegia maps to 10q22.110q24.1. Ann Neurol, Vol.56, No.4, (Oct 2004), pp. 579-582, ISSN 0364-5134

Miyatake, S., H. Tanabe, K. Yatabe, M. Suzuki, K. Ogata, H. Doi, N. Miyake, M. Kawai, and N. Matsumoto. (2011). Identification of a novel homozygous SACS gene mutation in ARSACS. Rinsho Shinkeigaku, Vol.51, No.12, (Dec 2011), (in press), ISSN 0009918X

Ogawa, T., Y. Takiyama, K. Sakoe, K. Mori, M. Namekawa, H. Shimazaki, I. Nakano, and M. Nishizawa. (2004). Identification of a SACS gene missense mutation in ARSACS. Neurology, Vol.62, No.1, (Jan 2004), pp. 107-109, ISSN 0028-3878

Okawa, S., M. Sugawara, S. Watanabe, T. Imota, and I. Toyoshima. (2006). A novel sacsin mutation in a Japanese woman showing clinical uniformity of autosomal recessive spastic ataxia of Charlevoix-Saguenay. J Neurol Neurosurg Psychiatry, Vol.77, No.2, (Feb 2006), pp. 280-282, ISSN 0022-3050

Ouyang, Y., K. Segers, O. Bouquiaux, F. C. Wang, N. Janin, C. Andris, H. Shimazaki, K. Sakoe, I. Nakano, and Y. Takiyama. (2008). Novel SACS mutation in a Belgian family with sacsin-related ataxia. J Neurol Sci, Vol.264, No.1-2, (Jan 2008), pp. 73-76, ISSN 0022-510X 
Ouyang, Y., Y. Takiyama, K. Sakoe, H. Shimazaki, T. Ogawa, S. Nagano, Y. Yamamoto, and I. Nakano. (2006). Sacsin-related ataxia (ARSACS): expanding the genotype upstream from the gigantic exon. Neurology, Vol.66, No.7, (Apr 2006), pp. 11031104, ISSN 1526-632X

Parfitt, D. A., G. J. Michael, E. G. Vermeulen, N. V. Prodromou, T. R. Webb, J. M. Gallo, M. E. Cheetham, W. S. Nicoll, G. L. Blatch, and J. P. Chapple. (2009). The ataxia protein sacsin is a functional co-chaperone that protects against polyglutamine-expanded ataxin-1. Hum Mol Genet, Vol.18, No.9, (May 2009), pp. 1556-1565, ISSN 1460-2083

Peyronnard, J. M., L. Charron, and A. Barbeau. (1979). The neuropathy of CharlevoixSaguenay ataxia: an electrophysiological and pathological study. Can J Neurol Sci, Vol.6, No.2, (May 1979), pp. 199-203, ISSN 0317-1671

Richter, A. M., R. K. Ozgul, V. C. Poisson, and H. Topaloglu. (2004). Private SACS mutations in autosomal recessive spastic ataxia of Charlevoix-Saguenay (ARSACS) families from Turkey. Neurogenetics, Vol.5, No.3, (Sep 2004), pp. 165-170, ISSN 1364-6745

Richter, A., K. Morgan, J. P. Bouchard, J. Mathieu, J. Lamarche, J. Rioux, et al. (1996). ARSACS: possibly a lysosomal storage disease? Am J Hum Genet, Vol.59, (1996), pp. A379, ISSN 0002-9297

Shimazaki, H., I. Nakano, and Y. Takiyama. (2008). Brain MRI and SPECT findings in ARSACS. Rinsho Shinkeigaku, Vol.48, No.12, (Dec 2008), p. 1208, ISSN 0009-918X

Shimazaki, H., K. Sakoe, K. Niijima, I. Nakano, and Y. Takiyama. (2007). An unusual case of a spasticity-lacking phenotype with a novel SACS mutation. J Neurol Sci, Vol.255, No.1-2, (Apr 2007), pp. 87-89, ISSN 0022-510X

Shimazaki, H., Y. Takiyama, J. Honda, K. Sakoe, M. Namekawa, J. Tsugawa, Y. Tsuboi, C. Suzuki, M. Baba, and I. Nakano. (2012). Middle Cerebellar Peduncles and Pontine T2 Hypo-intensities in ARSACS. J Neuroimaging, (Jan 23 2012), [Epub ahead of print], ISSN 1552-6569

Shimazaki, H., Y. Takiyama, K. Sakoe, Y. Ando, and I. Nakano. (2005). A phenotype without spasticity in sacsin-related ataxia. Neurology, Vol.64, No.12, (Jun 2005), pp. 21292131, ISSN 0028-3878

Simpson, M. A., H. Cross, C. Proukakis, A. Pryde, R. Hershberger, A. Chatonnet, M. A. Patton, and A. H. Crosby. (2003). Maspardin is mutated in mast syndrome, a complicated form of hereditary spastic paraplegia associated with dementia. Am J Hum Genet, Vol.73, No.5, (Nov 2003), pp. 1147-1156, ISSN 0002-9297

Takado, Y., K. Hara, T. Shimohata, S. Tokiguchi, O. Onodera, and M. Nishizawa. (2007). New mutation in the non-gigantic exon of SACS in Japanese siblings. Mov Disord, Vol.22, No.5, (Apr 2007), pp. 748-749, ISSN 0885-3185

Takiyama, Y. (2006). Autosomal recessive spastic ataxia of Charlevoix-Saguenay. Neuropathology, Vol.26, No.4, (Aug 2006), pp. 368-375, ISSN 0919-6544

Takiyama, Y. (2007). Sacsinopathies: sacsin-related ataxia. Cerebellum, Vol.6, No.4, (Feb 2007), pp. 353-359, ISSN 1473-4222

Terracciano, A., C. Casali, G. S. Grieco, D. Orteschi, S. Di Giandomenico, L. Seminara, R. Di Fabio, R. Carrozzo, A. Simonati, G. Stevanin, M. Zollino, and F. M. Santorelli. (2009). An inherited large-scale rearrangement in SACS associated with spastic ataxia and hearing loss. Neurogenetics, Vol.10, No.2, (Apr 2009), pp. 151-155, ISSN 1364-6753 
Terracciano, A., N. C. Foulds, A. Ditchfield, D. J. Bunyan, J. A. Crolla, S. Huang, F. M. Santorelli, and S. R. Hammans. (2010). Pseudodominant inheritance of spastic ataxia of Charlevoix-Saguenay. Neurology, Vol.74, No.14, (Apr 2010), pp. 1152-1154, ISSN 1526-632X

Tsugawa, J., Y. Tsuboi, Y. Naitou, S. Ohma, H. Shimazaki, Y. Takiyama, and M. Yamada. (2009). Novel compound heterozygous mutations in a family with sacsin-related ataxia. Mov Disord, Vol.24, No.S1, (Jun 2009), p. S1, ISSN 1531-8257

Van Damme, P., P. Demaerel, W. Spileers, and W. Robberecht. (2009). Autosomal recessive spastic ataxia of Charlevoix-Saguenay. Neurology, Vol.72, No.20, (May 2009), p. 1790, ISSN 1526-632X

Vermeer, S., R. P. Meijer, B. J. Pijl, J. Timmermans, J. R. Cruysberg, M. M. Bos, H. J. Schelhaas, B. P. van de Warrenburg, N. V. Knoers, H. Scheffer, and B. Kremer. (2008). ARSACS in the Dutch population: a frequent cause of early-onset cerebellar ataxia. Neurogenetics, Vol.9, No.3, (Jul 2008), pp. 207-214, ISSN 1364-6745

Vingolo, E. M., R. Di Fabio, S. Salvatore, G. Grieco, E. Bertini, V. Leuzzi, C. Nesti, A. Filla, A. Tessa, F. Pierelli, F. M. Santorelli, and C. Casali. (2011). Myelinated retinal fibers in autosomal recessive spastic ataxia of Charlevoix-Saguenay. Eur J Neurol, (Jan 2011), [Epub ahead of print], ISSN 1468-1331

Wilkinson, P. A., A. H. Crosby, C. Turner, L. J. Bradley, L. Ginsberg, N. W. Wood, A. H. Schapira, and T. T. Warner. (2004). A clinical, genetic and biochemical study of SPG7 mutations in hereditary spastic paraplegia. Brain, Vol.127, Pt 5, (May 2004), pp. 973-980, ISSN 0006-8950

Yamamoto, Y., K. Hiraoka, M. Araki, S. Nagano, H. Shimazaki, Y. Takiyama, and S. Sakoda. (2005). Novel compound heterozygous mutations in sacsin-related ataxia. J Neurol Sci, Vol.239, No.1, (Dec 2005), pp. 101-104, ISSN 0022-510X

Yamamoto, Y., M. Nakamori, K. Konaka, S. Nagano, H. Shimazaki, Y. Takiyama, and S. Sakoda. (2006). Sacsin-related ataxia caused by the novel nonsense mutation Arg4325X. J Neurol, Vol.253, No.10, (Oct 2006), pp. 1372-1373, ISSN 0340-5354 


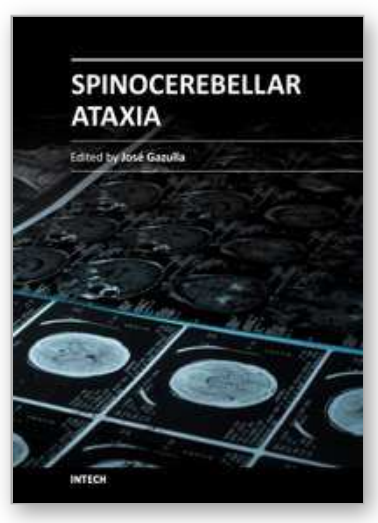

\author{
Spinocerebellar Ataxia \\ Edited by Dr. José Gazulla
}

ISBN 978-953-51-0542-8

Hard cover, 198 pages

Publisher InTech

Published online 18, April, 2012

Published in print edition April, 2012

The purpose of this book has been to depict as many biochemical, genetic and molecular advances as possible, in the vast field of the spinocerebellar ataxias.

\title{
How to reference
}

In order to correctly reference this scholarly work, feel free to copy and paste the following:

Haruo Shimazaki and Yoshihisa Takiyama (2012). Autosomal Recessive Spastic Ataxia of CharlevoixSaguenay (ARSACS): Clinical, Radiological and Epidemiological Aspects, Spinocerebellar Ataxia, Dr. José Gazulla (Ed.), ISBN: 978-953-51-0542-8, InTech, Available from:

http://www.intechopen.com/books/spinocerebellar-ataxia/sacsinopathies-sacsin-related-ataxia

\section{INTECH}

open science | open minds

\section{InTech Europe}

University Campus STeP Ri

Slavka Krautzeka 83/A

51000 Rijeka, Croatia

Phone: +385 (51) 770447

Fax: +385 (51) 686166

www.intechopen.com

\section{InTech China}

Unit 405, Office Block, Hotel Equatorial Shanghai

No.65, Yan An Road (West), Shanghai, 200040, China 中国上海市延安西路65号上海国际贵都大饭店办公楼 405 单元 Phone: +86-21-62489820

Fax: $+86-21-62489821$ 
(C) 2012 The Author(s). Licensee IntechOpen. This is an open access article distributed under the terms of the Creative Commons Attribution 3.0 License, which permits unrestricted use, distribution, and reproduction in any medium, provided the original work is properly cited. 